\title{
What's new in
}

\section{cardiovascular drugs?}

Developments in the medical therapy of patients with cardiovascular disease have confronted anaesthetists with an array of new cardioactive medications which patients are receiving on a chronic basis. New anti-hypertensives, antiarrhythmics, anti-anginal medications and inotropic agents, each with specific, and generally dose-related effects on the perioperative cardiovascular course, have come into widespread use. Furthermore, new rapidly acting cardiovascular medications, which provide enhanced titratability and favourable side-effect profiles, have provided important advances in the therapeutic armamentarium available to the anaesthetist.

In this lecture, the clinical pharmacology of several of the newer cardiovascular medications within each major class of drugs will be presented. General comments on practical clinical applications, and an overview of pharmacological benefits, and costs, will be provided.

\section{New perspectives on $\beta$-adrenergic blocking drugs}

The concept of modifying the level of $\beta$-adrenergic blockade in the perioperative period has undergone a complete reversal since propranolol became commercially available in the late 1950's. In 1972 Viljoen et al. investigated the effects of $\beta$-adrenergic blockade in patients undergoing general anaesthesia, and suggested that propranolol should be withdrawn perioperatively in patients who were receiving this medication. ${ }^{1}$ This practice, however, resulted in an exacerbation of dysrhythmias, hypertension, and myocardial ischaemia in many patients. In 1975, Kaplan et al. demonstrated that continued administration of propranolol for up to $48 \mathrm{hr}$ prior to surgery exerted no influence on the incidence of hypotension or bradycardia, compared with patients who were not receiving these medications. ${ }^{2}$ From the findings of these, and other clinical studies, it has now become routine clinical practice to continue $\beta$-adrenergic blocking medications in their usual doses, up to and including the morning of surgery.

More recent studies have shown that prophylactic administration of $\beta$-adrenergic blocking medications can reduce the adverse consequences of adrenergic stimulation, including tachycardia, hypertension, cardiac dysrhythmias, perioperative myocardial ischaemia, and acute myocardial infarction. ${ }^{3-6}$ Accordingly, the pendulum has now swung from the earlier approach of withdrawing $\beta$ blocking drugs prior to surgery, to the current practice
Donald R. Miller MD FRCPC

of maintaining the usual $\beta$-blocking regimen, and now to suggesting prophylactic administration of these drugs to patients who are at risk of developing cardiovascular complications in the perioperative period.

\section{Esmolol}

Esmolol is a cardioselective, $\beta_{1}$-adrenergic blocking drug which is characterized by an extremely rapid onset of effect (one to two minutes) and short duration of action (approximately four to eight minutes) following administration of a single bolus. ${ }^{7}$ The pharmacological properties of esmolol are compared with those of other representative intermediate-duration and long-acting $\beta$-blockers in Table I. The evanescent effects of esmolol result from a short elimination half-life of 9-12 $\mathrm{min}$, due to rapid hydrolysis of the ester linkage by red blood cell esterases. ${ }^{8}$ The RBC esterase is different from plasma cholinesterase, and is not inhibited to any considerable degree by physostigmine. Accordingly, there are no important clinical interactions between esmolol and other ester-containing drugs. Furthermore, at the highest infusion rates, esmolol does not prolong the neuromuscular block associated with the administration of succinylcholine.

It is important to appreciate that $\beta_{1}$ selectivity is relative rather than absolute, and that $\beta$-blocking effects can be seen in all tissues if sufficient drug levels are attained. The effects of $\beta_{1}$ and $\beta_{2}$ adrenergic stimulation are presented in Table II. In animal studies, esmolol has been shown to have a $40: 1$ affinity for the $\beta_{1}$ receptor, but the exact level of specificity in humans is unknown. The clinical significance of $\beta_{1}$ selectivity is the avoidance of effects on systemic and coronary vascular resistance (both of which increase with propranolol). More importantly, cardioselective $\beta$-blockers do not increase bronchomotor tone at clinically relevant doses, which is of particular importance for many COPD patients who have increased airway reactivity. Although esmolol has been used safely in low doses in asthmatics, caution is advised when using any $\beta$-blocking drug in these patients.

Practically speaking, the three main features of esmolol which make this drug clinically useful in the perioperative setting include its intravenous formulation, cardio-

From the Department of Anaesthesia, Ottawa General Hospital and The University of Ottawa, Ottawa, Ontario. 
TABLE I Representative $\beta$-blocking drugs

\begin{tabular}{llllll}
\hline Class & Elimination & $t_{1 / 2} \beta(h r)$ & $\beta_{\text {r-Selective }}$ & ISA & $M S A$ \\
\hline $\begin{array}{c}\text { Ultra-short } \\
\text { esmolol }\end{array}$ & $\begin{array}{l}\text { RBC } \\
\text { esterases }\end{array}$ & $9 \mathrm{~min}$ & Yes & \pm & \pm \\
$\begin{array}{c}\text { Intermediate } \\
\text { metoprolol }\end{array}$ & hepatic & $3-4$ & Yes & 0 & 0 \\
$\begin{array}{c}\text { Long } \\
\text { propranolol }\end{array}$ & hepatic & $4-6$ & No & 0 & ++ \\
$\begin{array}{c}\text { Ultra-long } \\
\text { nadolol }\end{array}$ & renal & $14-24$ & No & 0 & 0 \\
\hline
\end{tabular}

Pharmacokinetic properties of representative $\beta$-adrenergic blocking drugs. $t_{1 / 2} \beta=$ elimination half-life; ISA $=$ intrinsic sympathomimetic activity; $\mathrm{MSA}=$ membrane stabilizing activity. $++=$ strongly present; $\pm=$ marginally present; $0=$ absent.

TABLE Il Effects of $\beta$-adrenergic stimulation

\begin{tabular}{|c|c|}
\hline Location & Autonomic response \\
\hline \multicolumn{2}{|l|}{$\boldsymbol{\beta}_{1}$} \\
\hline \multirow[t]{4}{*}{ Heart } & I HR \\
\hline & 1 Inotropy \\
\hline & I Conduction velocity \\
\hline & Excitability \\
\hline Kidneys & Renin release \\
\hline Adipose tissues & FFA acid release \\
\hline \multicolumn{2}{|l|}{$\boldsymbol{\beta}_{2}$} \\
\hline Peripheral vessels & Arteriolar dilatation \\
\hline Bronchial muscle & Bronchodilatation \\
\hline Pancreas & Insulin release \\
\hline
\end{tabular}

selectivity, and short half-life. A short duration of clinical effect permits enhanced titratability, and an increased margin of safety when it is felt that a patient may benefit from $\beta$-adrenergic blockade, but there is uncertainty about possible side effects. A single bolus of esmolol, $0.5-1.5 \mathrm{mg} \cdot \mathrm{kg}^{-1}$ is efficacious for both prevention and treatment of tachycardia and hypertension, and myocardial ischaemia associated with tracheal intubation, during maintenance of anaesthesia, and at emergence. ${ }^{9,10}$ The drug, however, should be reserved for those patients with known or suspected coronary artery disease, where it is likely to be of greatest potential benefit. For prolonged increases in autonomic stimulation, esmolol can be given by continuous infusion, beginning with a loading dose of $0.3-0.5 \mathrm{mg} \cdot \mathrm{kg}^{-1}$, and maintained at rates between $50-200 \mu \mathrm{g} \cdot \mathrm{kg}^{-1} \cdot \mathrm{min}^{-1}$, titrated to the desired heart rate response. Finally, as an antiarrhythmic, esmolol is effective for the treatment of atrioventricular nodal tachycardia, atrial fibrillation/flutter, and multinodal atrial tachycardia.

The cost of esmolol is $\$ 9.40 / 100 \mathrm{mg}$ (10 ml vial). Although a more concentrated solution is available for long-
TABLE III Calcium channel blockers

- Benzothiapines: diltiazem

- Phenylalkyamines: verapamil

- 1,4-dihydropyridine derivatives: nifedipine, nicardipine, nitrendipine

term infusions, the $100 \mathrm{mg}$ vial is an appropriate format for both bolus administration and short-term infusions of this drug. Once the appropriate level of $\beta$-blockade has been established with esmolol $(0.5-2.0 \mathrm{hr})$, it may be appropriate and more cost-effective to switch to a longer-acting drug such as metoprolol (\$4.64/5 mg vial). By comparison, iv propranolol costs $\$ 6.00 / 1 \mathrm{mg}$ vial.

\section{Contraindications to $\beta$-blockade}

As with any $\beta$-blocking drug, esmolol is contraindicated in patients with either left or right ventricular dysfunction, and those with heart failure or non-compensatory tachycardia of any aetiology. Additionally, esmolol should not be given to patients with sinus bradycardia (HR $<60$ beats $\cdot \min ^{-1}$ ) and should not be given in the presence of second or third degree atrio-ventricular block, or to patients with significant aortic or mitral stenosis. Esmolol's cardioselectivity makes this $\beta$-blocking drug useful for patients with obstructive airways disease who may have a reactive airways component, but it would be prudent to avoid giving it to patients with a history of asthma. Finally, as with any $\beta$-blocking drug, esmolol should not be given to patients with phaeochromocytoma unless they are also receiving alpha-adrenergic blocking drugs.

\section{Calcium channel blockers: new drugs and new roles}

Calcium channels are functional pores in membranes through which calcium flows down an electrochemical gradient when they are open. The channels are found in both cardiac and smooth muscle, in addition to other cellular membranes, and are also a component of the sarcoplasmic reticulum and mitochondria. Calcium functions as a primary generator of the cardiac action potential and as an intracellular second messenger. Calcium channel blockers interact with the "L-type" calcium channel, and are composed of drugs of three different classes (Table III).

Calcium channel blockers are known to interact in an additive fashion with the inhalational anaesthetics on depressing slow channel kinetics. "In addition, there is evidence that the calcium entry blockers interact with the non-depolarizing neuromuscular blocking drugs in a fashion similar to that with the "mycin" antibiotics. ${ }^{12} \mathrm{Al}$ though this interaction is not well defined, there is a suggestion of a reduced margin of safety with this combination of drugs. Despite these considerations, clin- 
ical experience has shown that, as with the $\beta$-adrenergic blocking drugs, calcium channel blocking drugs should be maintained until the time of surgery to control angina pectoris, hypertension or cardiac dysrhythmias. ${ }^{12}$ It is possible that sudden discontinuation of these drugs could result in a rebound of symptoms, although such occurrences have not been reported.

\section{Nifedipine}

Nifedipine, like all dihydropyridine derivatives, is a potent arteriolar dilator which has minimal venodilating effects. Reflex activation of the sympathetic nervous system may be associated with increases in both heart rate and contractility. The negative inotropic effects of nifedipine are generally offset by the decrease in systemic vascular resistance, with an associated increase in cardiac output. All the dihydropyridine derivatives are excellent antihypertensive medications due to their arterial vasodilatory effects.

Nifedipine's oral bioavailability is approximately $70 \%$, with peak plasma concentrations occurring within 30-45 $\mathrm{min}$ of administration. The drug is $95 \%$ protein bound and has an elimination half-life of five hours. One disadvantage of nifedipine is that a parenteral formulation is not approved, because the compound degrades rapidly in the presence of light and moisture, preventing formulation of commercially available preparations. However, puncture of the capsule and sublingual or intranasal administration provides an onset of effect in two to three minutes. ${ }^{13}$

\section{Nifedipine for postoperative hypertension}

Postoperative hypertension occurs in approximately $30-60 \%$ of patients following coronary artery bypass and aortic reconstructive surgery, and produces considerable haemodynamic stress, which may predispose to bleeding, myocardial ischaemia, and postoperative myocardial infarction. ${ }^{14}$ Furthermore, it has been shown that myocardial lactate extraction may actually decrease during postoperative hypertension, as evidenced by heterogeneous anaerobic myocardial metabolism. ${ }^{15}$ Over the past $15 \mathrm{yr}$, nitroprusside has assumed a preeminent role in the therapy of postoperative hypertension. Although nitroprusside is very effective in controlling postoperative hypertension, its use may be associated with cyanide and thiocyanate poisoning, and a reduction of arterial oxygen tension as a result of inhibition of adaptive hypoxic pulmonary vasoconstriction. Furthermore, it has also been shown that nitroprusside therapy for postoperative hypertension is associated with a reversal to myocardial lactate production without a decrease in coronary sinus blood flow, suggesting the presence of intra-coronary steal. ${ }^{15}$

These concerns should give rise to consideration of other therapeutic options for perioperative hypertension, in patients who may be prone to myocardial ischaemia. Recently, Mullen et al. compared the efficacy and cardiometabolic effects of nifedipine with diltiazem and nitroprusside for post-coronary bypass hypertension. ${ }^{16}$ It was found that when all three drugs were administered in sufficient doses to attain and maintain mean arterial pressure around $90 \mathrm{mmHg}$, that myocardial performance (the relationship between left ventricular stroke work index and end-diastolic volume) was depressed most by diltiazem, and to a lesser extent with nifedipine, but not by nitroprusside. In contrast, in response to the stress of atrial pacing, myocardial lactate flux decreased with nitroprusside, but not with diltiazem or nifedipine.

At present, nitroprusside remains a very efficacious drug for controlling postoperative hypertension, but the drug may be deleterious for patients who have postoperative myocardial ischaemia. Nifedipine may therefore be an important adjunct when increased contractility accompanies postoperative hypertension, and may result in improved myocardial metabolism. However, the calcium antagonists should be used cautiously in patients with limited ventricular reserve. Parenteral formulations of nifedipine and diltiazem are not yet approved in Canada.

To treat perioperative hypertension, nifedipine can be administered either sublingually or intra-nasally. The initial dose is $10-20 \mathrm{mg}$, repeated in $15-20 \mathrm{~min}$ if necessary. The main advantages of this drug for treating perioperative hypertension include its efficacy, favourable cardiometabolic effects, and low cost (\$0.12/10 mg capsule).

\section{Nicardipine}

Nicardipine has pharmacological effects which are similar to those of nifedipine, but exhibits increased vascular selectivity for the coronary and vascular beds, and has a much longer duration of action. Peak plasma concentrations are reached one hour after oral administration, with a bioavailability of $35 \%$. The drug undergoes extensive hepatic biotransformation, with an elimination half-life of 8-9 hr. Although less than $1 \%$ of the drug is renally excreted, plasma concentrations have been shown to increase in patients with renal failure. Appropriate adjustments in dosing should be made for such patients.

Although not yet approved in Canada, nicardipine may be of clinical use in the perioperative setting because it can be given parenterally. This may make the drug useful for the management of postoperative hypertension, particularly for individuals who are at risk for development of myocardial ischaemia. This is because nicardipine produces market improvements in coronary blood flow, which is thought to be the result of direct coronary vasodilation. In addition, nicardipine produces positive 
inotropic effects with either phospodiesterase activity or calcium channel agonist activity, which results in autoregulatory increases in coronary blood flow.

\section{Nitrendipine}

Nitrendipine is a dihydropyridine derivative which differs from nifedipine by being a more selective vascular dilator, and having fewer myocardial depressive effects. Nitrendipine also has clinically important natriuretic and diuretic effects, although renal blood flow and glomerular filtration rate do not change with this drug. The main clinical advantage of nitrendipine is that its long elimination half-life (8-10 hr) allows convenient once-a-day therapy for patients with hypertension and congestive heart failure. The prolonged duration of clinical effect should be taken into consideration when prescribing this drug preoperatively.

\section{Other new antihypertensive medications}

The renin-angiotensin-aldosterone (RAA) system plays an important role in the pathogenesis of hypertension. Accordingly, the recent introduction of a parenteral formulation of angiotension-converting enzyme (ACE) inhibitor (enaliprilat $i v$ ), has provided an opportunity to re-examine the therapeutic advantages of this class of drugs in treating urgent hypertenisive conditions in the perioperative period. Potential advantages of an injectable ACE inhibitor include ease of administration (single boluses iv $\mathrm{q} 6 \mathrm{H}$ ), and more importantly, the fact that this class of drugs generally achieves a controlled reduction in blood pressure, while at the same time preserving vital organ blood flow.

Renin is released primarily from the renal juxtaglomerular apparatus in response to changes in blood pressure. It cleaves the glycoprotein angiotensinogen contained in the plasma, to form the decapeptide Angiotensin 1. Angiotensin-converting enzyme, or ACE, acts on angiotensin I to form the octapeptide Angiotensin II. Angiotensin is one of the most powerful pressor substances known, and raises blood pressure directly by vasoconstriction of the arterial vascular bed, and indirectly by stimulating aldosterone secretion from the adrenal glands, thus promoting sodium and water retention. Under normal circumstances, a feedback loop controls renin release, but in many forms of hypertension, an inappropriately high level of activity in the RAA system leads to high circulating and/or tissue concentrations of angiotensin II, which may lead to accelerated hypertension. Such mechanisms may also play an important role in the pathophysiology of perioperative hypertension. ${ }^{17}$

\section{Enaliprilat}

At present, enaliprilat is the only ACE inhibitor which has been approved for parenteral administration. This drug has been shown to be effective in lowering both systolic and diastolic pressure in patients with severe and accelerated hypertension. ${ }^{18}$ The dominant action of the drug is to reduce the level of angiotensin-converting enzyme, and the consequent reduction of Angiotensin II. It has been suggested that $A C E$ inhibitors may be ineffective in patients with normal plasma renin activity, but studies have shown that the hypotensive response to this group of drugs is unrelated to the basal level of renin plasma activity or to the lowering of plasma levels of Angiotensin II, ${ }^{19}$ which implicates the possible role of increased production of vasodilatory prostaglandins or other mechanisms to explain the antihypertensive effects.

In addition to its demonstrated efficacy in controlling hypertensive urgencies, $i v$ enaliprilat is also efficatious in moderating the haemodynamic response to tracheal intubation..$^{20,21}$ However, the relatively slow onset of enaliprilat (15 min) and transient nature of such intraoperative stimuli may make this drug more suitable for use in situations where the rises in blood pressure tend to be more gradual and sustained, ${ }^{22,23}$ such as occur during the postoperative period. The drug may therefore be of greatest potential benefit in controlling post-coronary artery bypass hypertension, and hypertension following major vascular surgery. The recommended initial dose of enaliprilat is $1.25 \mathrm{mg} \dot{\nu}$ given over five minutes, and then repeated $\mathrm{q} 6 \mathrm{~h}$. If the clinical response is inadequate, the initial dose may be repeated after one hour. The cost of such treatment is approximately $\$ 42 /$ day (Enaliprilat $\$ 20.79 / 2.5 \mathrm{mg}$ vial). For patients with renal impairment, or where there is a risk of hypotension, the dosage should be reduced by approximately one-half. The onset of action is approximately $15 \mathrm{~min}$, with the maximum antihypertensive effect occurring with one to four hours. Although enaliprilat is only indicated for the treatment of hypertension, the drug has been shown to moderate increases in left ventricular end-diastolic and pulmonary artery pressures, and secondarily increasing cardiac output and stroke volume.

In general, the safety and tolerability of $i v$ enaliprilat is similar to that of the oral compound. The most common side effect is hypotension, which occurs in approximately $4 \%$ of patients. Hypotension is most likely to occur in individuals who have either heart failure or hyponatremia, and those who have received recent intense diuresis. Hypotension can usually be minimized by reducing the initial dose of the drug, and/or by providing concomitant volume loading. Furthermore, the antihypertensive effect of enaliprilat may be augmented by antihypertensive drugs that cause renin release (e.g., diuretics). As enaliprilat attenuates the potassium loss caused by diuretics, the adjunctive use of potassium- 
sparing diuretics with enaliprilat warrants close monitoring of serum potassium concentrations.

\begin{abstract}
Anti-arrhythmics: new drugs and new indications
The frequency of cardiac arrhythmias during anaesthesia and surgery depends on the definition of the arrhythmia, and the sensitivity of the method used to detect it. The reported incidence varies widely between studies, but may approach $100 \%$, depending on definitions and monitoring techniques. ${ }^{24}$ Fortunately, despite such a high incidence, sustained or serious rhythm disorders which require either pharmacological or electrical cardioversion are infrequent. Where treatment is indicated for supraventricular arrhythmias, adenosine is a new drug which offers unique advantages in the perioperative setting. For ventricular fibrillation which is unresponsive to other medications, and for the management of Torsades des Pointes, new indications have been found for an old medication: magnesium sulphate.
\end{abstract}

\section{Adenosine}

Adenosine is a naturally occurring purine nucleoside, which was first described in 1929, but which has only recently been approved for clinical use in Canada. The drug is now considered the treatment of choice for reentrant supraventricular tachycardia, ${ }^{25,26}$ by prolonging the conduction time of the AV node, and by terminating $\mathrm{AV}$ nodal re-entry. Adenosine also acts by depressing sinus node and ventricular automaticity at higher doses.

The remarkable feature of adenosine is its extremely rapid onset and brief duration of effect (elimination halflife $=1.5 \mathrm{sec}$ ). Although the efficacy of adenosine for the treatment of paroxysmal supraventricular tachycardia is similar to that of verapamil, adenosine lacks the vasodilator and negative inotropic effects of the latter. On the other hand, adenosine is frequently associated with transient but unpleasant side effects including chest discomfort, dyspnoea, and facial flushing, although these rarely persist beyond one to two minutes. The exception is bronchoconstriction, which can persist for over an hour. The action of adenosine is antagonized by theophylline derivatives, but may be potentiated by dipyridamole.

The recommended initial dose of adenosine is $6 \mathrm{mg}$ $i v$ for adults, given over two to four seconds. If no response is observed within one to two minutes, a $12 \mathrm{mg}$ dose should be given in the same manner. It is important that adenosine be administered rapidly via a free-flowing $i v$ line, as the drug is completely metabolized in less than one minute. Due to its short duration of clinical effect, tachyarrhythmias may recur, requiring additional doses of adenosine or a calcium channel antagonist. The cost of adenosine is $\$ 29.50 / 6 \mathrm{mg}$ in a $2 \mathrm{ml}$ vial.

Adenosine also has several important drug interactions.
Patients taking theophylline derivatives may require larger doses, as the methylxanthines block the receptor responsible for adenosine's electrophysiological and haemodynamic effects. Also, dipyridamole blocks adenosine uptake and potentiates its effects, as the action of adenosine is also prolonged in patients receiving carbamazepine.

\section{Magnesium sulphate}

Magnesium is an abundant, intracellular divalent cation which may be deficient in critically ill patients, especially in chronic situations. Functionally, magnesium is a primary regulator or co-factor in many enzyme systems, and is required for maintenance of the membrane-bound $\mathrm{Na}^{+} / \mathrm{K}^{+}$-ATPase, which is the principal enzyme that maintains normal intracellular potassium concentration. Hypomagnasaemia, (defined as $[\mathrm{Mg}]<1.7 \mathrm{mg} \cdot \mathrm{dl}^{-1}$ ) has recently been shown to occur commonly following cardiac surgery, ${ }^{27}$ and may be associated with a number of cardiovascular disturbances, including arrhythmias, heart failure, coronary spasm, and sudden cardiac death. ${ }^{28}$ In addition, as with hypokalaemia, magnesium deficiency exacerbates the potential for arrhythmias with the digitalis glycosides. ${ }^{29}$ The ECG findings associated with hypomagnasaemia are similar to those associated with hypokalaemia, including prolongation of the P-R and Q-T intervals, increased QRS duration, and STsegment abnormalities. The non-cardiovascular manifestations of hypomagnasaemia include latent or overt tetany, weakness, a decreased level of consciousness and seizures, as well as dysphagia, anorexia and nausea.

It is well established that arrhythmias induced by magnesium deficiency may be refractory to treatment with anti-arrhythmic drugs, as well as electrical cardioversion or defibrillation. For this reason, treatment of refractory arrhythmias with magnesium has been advocated even when hypomagnasaemia has not been documented. Furthermore, magnesium is now recommended as the drug of choice for treatment of Torsades des Pointes, a polymorphic type of ventricular tachycardia.

The role of magnesium in sudden cardiac death is now also being re-examined. ${ }^{30}$ Acute myocardial infarction associated with hypomagnasaemia carries an increased risk of congestive heart failure and sudden cardiac death, and recent evidence suggests that magnesium administration, even in the absence of hypomagnasaemia, may lower this risk. This may result from the ability of $\mathrm{Mg}^{++}$to attenuate catecholamine release, dilate the coronary arteries, and enhance prostacyclin release, resulting in diminished platelet adhesion and aggregation. Studies are currently underway to clarify the role of routine $\mathrm{Mg}$ administration in the setting of acute myocardial infarction. At the present time, it would seem prudent to recommend correction of hypomagnasaemia in the setting of myocar- 
TABLE IV Desired characteristics of the "ideal" inotrope

\begin{tabular}{l} 
- Increases contractility by 1 velocity and force of myocardial fibre \\
- Shortening \\
- No vasoconstriction \\
- No tachycardia \\
- Redistributes blood flow to vital organs \\
- Compatible with other vasoactive drugs \\
- Titratable; rapid onset and termination of action \\
- Cost-effective \\
\hline
\end{tabular}

dial ischaemia, ventricular arrhythmias, or congestive heart failure. For symptomatic or severe hypomagnasaemia $\left(\left[\mathrm{Mg}^{++}\right]<1 \mathrm{mg} \cdot \mathrm{dl}^{-1}\right)$, treatment should be with parenteral magnesium $1-2 \mathrm{~g}(8-16 \mathrm{mEq})$ bolus over the first hour, followed by a continuous infusion at a rate of $2-4 \mathrm{mEq} \cdot \mathrm{hr}^{-1}$. Therapy should be guided by the serum magnesium concentration, and the rate of infusion should not exceed $1 \mathrm{mEq} \cdot \min ^{-1}$, even in emergency situations. The ECG and blood pressure should be monitored during acute therapy, whereas for mild deficiencies, treatment can be managed by diet alone or oral $\mathrm{Mg}^{++}$ supplements.

\section{Advances in inotropic therapy}

A new group of drugs has been developed which approach the desired properties of the ideal inotropic agent (Table IV). These new phosphodiesterase inhibitors do not rely upon stimulation of the $\beta$-adrenergic or alphaadrenergic receptors, but rather act by the selective inhibition of PDE III. Accordingly, improvements in cardiac function can be achieved with this class of drugs, without increasing myocardial oxygen consumption. Both PDE I and II hydrolize all cyclic nucleotides, whereas PDE III acts specifically on cAMP, to impede its breakdown at the level of the cell membrane. Inside cardiac muscle, an increase in cAMP levels leads to increased phosphorylation, which increases the slow inward movement of the calcium current, promoting increased intracellular calcium stores, and hence increased inotropism.

\section{Amrinone}

Amrinone is a bipryridine derivative that produces mild inotropic activity and strong vasodilatory effects. ${ }^{31,32} \mathrm{Re}-$ markably, amrinone is the first oral inotrope available since the introduction of digitalis, although it is currently prescribed only in its parenteral form. Also, the drug has a high therapeutic index $\left(\mathrm{LD}_{50} / \mathrm{ED}_{50}\right)$ of approximately $100: 1$, compared with 1.2:1 with the digitalis glycosides. The enhanced margin of safety should prove to be of great benefit to patients receiving long-term therapy.

The drug provides a dose-related increase in cardiac
TABLE V Management of low cardiac output syndrome

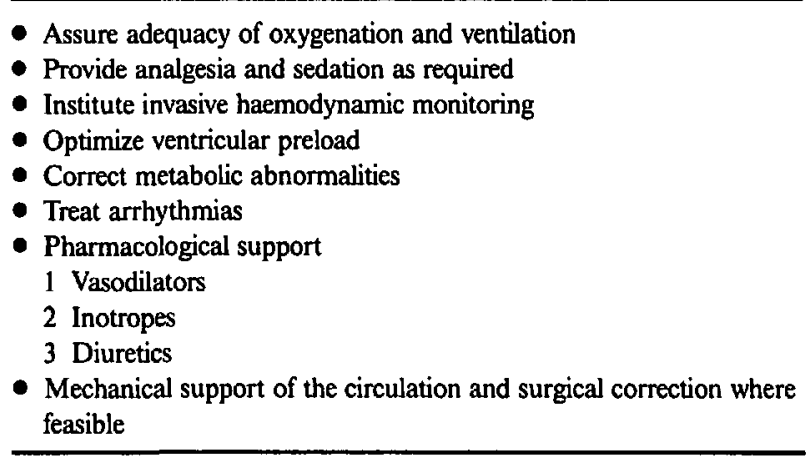

index and left ventricular stroke work index $(40-80 \%$ increase) associated with a decrease in both left ventricular end-diastolic pressure and systemic vascular resistance. Importantly, heart rate and mean arterial pressure are relatively unaffected. Peak response to an intravenous dose occurs within five minutes, and there is no evidence of tolerance over the short term ( $24 \mathrm{hr}$ ). The drug is compatible with other adrenergic agonists, and may also be used effectively in combination with other vasodilators such as hydralazine.

Intravenous amrinone therapy should begin with a loading dose of $0.75 \mu \mathrm{g} \cdot \mathrm{kg}^{-1}$ bolus given over two to three minutes, followed by a continuous infusion between 5-10 $\mu \mathrm{g} \cdot \mathrm{kg}^{-1} \cdot \mathrm{min}^{-1}$, according to the haemodynamic profile. An additional bolus of $0.75 \mu \mathrm{g} \cdot \mathrm{kg}^{-1}$ may be given 10-20 $\mathrm{min}$ after initiation of therapy. Caution should be given to avoiding rapid administration of bolus doses, as hypotension may ensue. In addition, there are two other side effects of amrinone which are uncommon but are of clinical importance. The first is thrombocytopenia which occasionally occurs in patients receiving long-term oral medication. Fortunately, this responds to a reduction in dosage, and has not been documented with parenteral (short-term) administration..$^{33}$ The second side effect is centrilobular hepatic necrosis, which has been produced in dogs receiving high doses of this medication for periods exceeding three months. Although such an occurrence has not been documented in humans, the drug should not be given to a patient receiving halothane.

Finally, treatment of low cardiac output syndrome should follow the general principles outlined in Table V. Therapy with amrinone is relatively expensive $(\$ 32.40 /$ $100 \mathrm{mg}$ ). In contrast, dopamine costs $\$ 1.02 / 200 \mathrm{mg}$, and dobutamine costs $\$ 31.30 / 250 \mathrm{mg}$. When selecting an inotrope for a specific situation, consideration should be given to the potential benefits of improving cardiac function without increasing myocardial oxygen consumption (amrinone) and reducing the requirements of concurrent vasodilator therapy (when using amrinone and to a lesser extent when using dobutamine). 


\section{Milrinone}

Milrinone is an experimental bipryridine inotropic drug that is a derivative of amrinone, but has approximately 20 times the potency of the parent compound. ${ }^{34}$ Milrinone is active in both intravenous and oral formulations, and has beneficial short-term haemodynamic effects in patients with severe refractory congestive heart failure. As with amrinone, improvement in heart failure is the result of enhanced contractility and peripheral vasodilation. However, efficacy in humans remains to be established.

\section{Conclusions}

Many new cardiovascular medications have become a mainstay of therapy for patients who undergo anaesthesia for both cardiac and non-cardiac surgery. In general, most of these medications should be continued in their usual doses up to and including the morning of surgery, and should then be re-instituted in the early postoperative period. It is important to appreciate the potential for drug interactions with the anaesthetic agents, as well as other cardioactive medications which may be administered perioperatively. In addition, a number of new, short-acting medications such as esmolol and adenosine, appear to be pharmacologically tailored for the perioperative control of tachycardia, arrhythmias and haemodynamic pertubations. Consideration of efficacy, ease of administration, side-effect profile, and cost-benefit (pharmacoeconomic) aspects will determine the ultimate role of all these new medications in our clinical practice.

\section{References}

1 Viljoen JF, Estafanous FG, Kellner GA. Propranolol and cardiac surgery. J Thorac Cardiovasc Surg 1972; 64: 826-30.

2 Kaplan JA, Dunbar RW, Bland JW, et al. Propranolol and cardiac surgery: a problem for the anesthesiologist? Anesth Analg 1975; 54: 571-8.

3 Kirshenbaum JM, Kloner RA, Antman AM. Use of an ultra-short acting $\beta$-blocker in patients with acute myocardial ischemia. Circulation 1985; 72: 873-80.

4 Kaplan JA. Role of ultra-short acting $\beta$-blockers in the perioperative period. J Cardiothorac Anesth 1988; 2: 683-92.

5 Stone JG, Foex P, Sear JW, Johnson LL, Khambatta HJ, Triner $L$. Myocardial ischaemia in untreated hypertensive patients: effect of a single small oral dose of a betaadrenergic blocking agent. Anesthesiology 1988; 68: 495-500.

6 Gray RJ, Bateman TM, Czer LSC, Conklin C, Matloff $J M$. Use of esmolol in hypertension after cardiac surgery. Am J Cardiol 1985; 56: 49F-56F.

7 Sintetos AL, Hulse J, Pritchett EL. Pharmacokinetics and pharmacodynamics of esmolol administered as an intravenous bolus. Clin Pharmacol Ther 1987; 41: 112-7.

8 Sum CY, Yacobi A, Kartzinel R, Stampfli $H$, Davis CS, Lai $C M$. Kinetics of esmolol, an ultra-short-acting betablocker, and of its major metabolite. Clin Pharmacol Ther 1983; 34: 427-34.

9 Miller DR, Martineau RJ, Wynands JE, Hill J. Bolus administration of esmolol for controlling the haemodynamic response to tracheal intubation: the Canadian Multicentre Trial. Can J Anaesth 1991; 38: 849-58.

10 Miller $D$, Martineau RJ. Bolus administration of esmolol for the treatment of intraoperative myocandial ischaemia. Can J Anaesth 1989; 36: 593-7.

11 Hysing ES, Chelly JE, Doursout MF, Hartley C, Merin $R G$. Cardiovascular effects of and interaction between calcium channel blocking drugs and anesthetics in chronically instrumented dogs. III. Nicardipine and isoflurane. Anesthesiology 1986; 65: 385-9.

12 Stoelting $R K$. Calcium entry blockers. In: Stoelting RK (Ed.). Pharmacology and Physiology in Anesthetic Practice, Philadelphia: JB Lippincott, 1987; 355.

13 Reves JG, Kissin I, Lell WA, Tosone S. Calcium entry blockers: uses and implications for the anesthesiologist. Anesthesiology 1982; 57: 504-18.

14 Taylor KM, Morton IJ, Brown JJ, Bain WH, Caves PK. Hypertension and the renin-angiotensin system following open-heart surgery. J Thorac Cardiovasc Surg 1977; 74: 840-5.

15 Fremes $S E$, Weisel RD, Baird RJ, et al. The effects of postoperative hypertension and its treatment. J Thorac Cardiovasc Surg 1983; 86: 47-56.

16 Mullen JC, Miller DR, Weisel RD, et al. Postoperative hypertension: a comparison of diltiazem, nifedipine, and nitroprusside. J Thorac Candiovasc Surg 1988; 96: 122-32.

17 Ferrario $C M$. The renin-angiotensin system: importance in physiology and pathology. J Cardiovasc Pharmacol 1990; 15: $\mathrm{S1}-5$.

18 Strauss $R$, Gavras I, Vlahakos D, Gavras H. Enaliprilat in hypertensive emergencies. J Clin Pharmacol 1986; 26: 39-43.

19 Gavras $H$. Angiotensin converting enzyme inhibition and its impact on cardiovascular disease. Circulation 1990; 81: 381-8.

20 Heropoulos $M$, Schleren H, Seltzer J, et al. The prophylactic effect of intravenous enaliprilat on intraoperative hypertension. Anesthesiology 1990; 75: A92.

21 Yates AP, Hunter DN. Anaesthesia and angiotensinconverting enzymes inhibitors. The effect of enalapril on perioperative cardiovascular stability. Anaesthesia 1988; 43: 935-8.

22 Rutledge J, Ayers C, Davidson $R$, et al. Effect of intravenous enaliprilat in moderate and severe systemic hypertension. Am J Cardiol 1988; 62: 1062-7. 
23 Todd PA, Heel RC. Enalapril: a review of its pharmacodynamic and pharmacokinetic properties, and therapeutic use in hypertension and congestive heart failure. Drugs 1986; 31: 198-248.

24 Casey WF, Wynands JE, Ramsay JG, et al. The incidence of dysrhythmias in patients undergoing coronary artery surgery. J Cardiothorac Anesth 1988; 2: 123-9.

25 Garratt C, Linker N, Griffith M, Ward D, Camm AJ. Comparisons of adenosine and verapamil for termination of paroxysmal junctional tachycardia. Am J Cardiol 1989; 64: 310-6.

26 Rankin $A C, M c$ Govern $B A$. Adenosine or verapamil for the acute treatment of supraventricular tachycardia? (Editorial). Ann Intern Med 1991; 114: 513-5.

27 Aglio LS, Stanford GG, Maddi R, Boyd JL 3rd, Nussbaum $S$, Chernow B. Hypomagnasemia is common following cardiac surgery. J Cardiothorac Vasc Anesth 1991; 5: 201-8.

28 Burch GE, Giles TD. The importance of magnesium deficiency in cardiovascular disease. Am Heart J 1977; 94: 649-7.

29 Chernow B, Smith J, Rainey TG, Finton C. Hypomagnasemia: implications for critical care specialists. Crit Care Med 1981; 10: 193-6.

30 Turlapaty PDMV, Altura BM. Magnesium deficiency produces spasms of coronary arteries: relationship to etiology of sudden death and ischemic heart disease. Science 1980; 208: 198-200.

31 Levy JH, Baily JM. Amrinone: pharmacokinetics and pharmacodynamics. J Cardiothorac Anesth 1989; 3: 10-4.

32 Hines $R$. Clinical applications of amrinone. J Cardiothorac Anesth 1989; 3: 24-32.

33 Braunwald $E$. A symposium: Amrinone. Introduction. Am J Cardiol 1985; 56: 1B-2B.

34 Baim DS, McDowell AV, Cherniles J, et al. Evaluation of a new bipyridine inotropic agent - milrinone - in patients with severe congestive heart failure. N Engl J Med 1983; 309: 748-56. 


\title{
La nouvelle médication cardiovasculaire
}

\author{
Donald R. Miller MD FRCPC
}

Les cardiaques qui se présentent pour une anesthésie reçoivent maintenant et souvent depuis longtemps plusieurs médicaments nouveaux. L'anesthésiste doit connaître les caractéristiques pharmacologiques des nouveaux antihypertenseurs, antiarythmiques, antiangineux et inotropes couramment utilisés. En plus, il dispose lui-même de nouvelles médications cardiovasculaires d'action rapide, plus faciles à doser et sans trop d'effets secondaires.

Cette conférence présentera, par classe de médicaments, la pharmacologie clinique de plusieurs de ces nouvelles acquisitions. Des commentaires généraux sur leurs applications pratiques seront formulés. Les bénéfices pharmacologiques et les coùts de ces drogues seront examinés.

\section{Nouvelles perspectives sur les inhibiteur $\beta$-adrénergiques} Le concept de la modification du niveau d'inhibition $\beta$ adrénergique à la période périopératoire a été complètement bouleversé depuis l'apparition du propanolol à la fin des années 50. En 1972, Viljoen et al. qui avaient étudié les effets du bloquage $\beta$-adrénergique en anesthésie générale, suggéraient de cesser le propanolol à la période périopératoire.' Cependant cette pratique a provoqué chez de nombreux patients l'exacerbation des arythmies, de l'hypertension et de l'ischémie myocardique. En 1975, Kaplan et al. démontraient que l'administration continue de propanolol jusqu'à 48 heures avant la chirurgie n'avait pas d'influence sur l'incidence de l'hypotension ou de la bradycardie. ${ }^{2}$ Sur la base de ces données et de d'autres études cliniques, on continue maintenant systématiquement la médication inhibitrice $\beta$-adrénergique à la dose usuelle, incluant le matin de la chirurgie.

Des études encore plus récentes montrent que l'administration prophylactique de $\beta$-bloquants diminue les effets nocifs de la stimulation adrénergique, dont la tachycardie, l'hypertension, les dysrythmies, l'ischémie cardiaque périopératoire et linfarctus du myocarde. ${ }^{3-6}$ L'arrêt préopératoire des $\beta$-bloquants est donc maintenant chose du passé et la pratique actuelle consiste à continuer la médication et même de l'administrer préventivement aux malades à risque de complications cardiovasculaires.

\section{L'esmolol}

L'esmolol est un inhibiteur cardiosélectif $\beta_{1}$-adrénergique caractérisé par un début d'action extrèmement rapide (une ou deux minutes) et une durée d'action brève (de quatre à huit minutes) lorsqu'il est administré en bolus. ${ }^{7}$ Les propriétés pharmacologiques de l'esmolol sont comparées au Tableau I à celles d'autres inhibiteurs $\beta$ adrénergiques à durée d'action intermédiaire et prolongée. Les effets fugaces de l'esmolol sont dus à sa courte demivie d'elimination (de neuf à $12 \mathrm{~min}$ ) par hydrolyse du lien ester par l'estérase érythrocytaire. ${ }^{8}$ L'estérase érythrocytaire est différente de la cholinestérase plasmatique et elle est peu inhibée par la physostigmine. Par conséquent, il n'existe pas d'interaction importante entre l'esmolol et les autre drogues estérifiées. De plus, même aux vitesses de perfusion les plus rapides, l'esmolol ninterfère pas avec le bloc neuromusculaire de la succinylcholine.

Il faut noter que la sélectivité $\beta_{1}$ est plus relative qu'absolue et qu'avec une concentration suffisante d'esmolol, tous les effets $\beta$-bloquants seront manifestes. Les effets de la stimulation adrénergique $\beta_{1}$ et $\beta_{2}$ sont présentés au Tableau II. Lors d'études animales, on a montré une affinité de 40:1 de l'esmolol pour les récepteurs $\beta_{1}$, mais on ne connaît pas le degré exact de cette spécificité chez Thumain. Cette sélectivité signifie cliniquement l'absence d'effets sur les résistances vasculaires coronaire et systémique (le propanolol les augmente toutes les deux). Mais ce qui est plus important, c'est qu'à doses cliniques les $\beta$-bloquants cardiosélectifs n'augmentent pas le tonus bronchomoteur; ceci revêt une importance particulière pour beaucoup de patients souffrant de MPOC, car ceuxci manifestent déjà une réactivité bronchique exagérée. Bien que des faibles doses d'esmolol aient déjà été utilisées sans problèmes chez l'asthmatique, il faut toujours être circonspect lorsqu'on administre des $\beta$-blocquants à ces malades.

Les trois caractéristiques pratiques de l'esmolol qui rendent ce médicament particulièrement utile à la période périopératoire sont sa présentation intraveineuse, sa cardiosélectivité et sa courte demi-vie. La brève durée de ses effets cliniques permet un meilleur dosage, et augmente la marge de sécurité lorsqu'on croit qu'un bloquage $\beta$-adrénergique sera bénéfique et qu'on n'est pas sûr sil $y$ aura des effets secondaires. Une seule dose d'esmolol $0,5-1,5 \mathrm{mg} \cdot \mathrm{kg}^{-1}$ est efficace pour la prévention et le traitement de la tachycardie et de l'hypertension, ainsi que de l'ischémie moycardique associées à l'intubation, pendant l'entretien de l'anesthésie et au réveil. ${ }^{9,10}$ Cepen- 
dant cette drogue doit être réservée à ceux qui en bénéficieront le plus, les coronariens soupçonnés ou connus. Pour combattre une stimulation sympathique prolongée, l'esmolol peut être administré en perfusion continue en commençant avec une dose d'attaque de 0,3 à 0,5 $\mathrm{mg} \cdot \mathrm{kg}^{-1}$, suivie d'une dose d'entretien de 50 à 200 $\mu \mathrm{g} \cdot \mathrm{kg}^{-1} \cdot \min ^{-1}$, ajustée à la fréquence cardiaque. Finalement, l'esmolol est un antiarythmique efficace contre la tachycardie atrioventriculaire nodale, la fibrillation et le flutter auriculaires, et la tachycardie auriculaire multinodale.

Il coûte $9,40 \$$ pour $100 \mathrm{mg}$ (ampoule de $10 \mathrm{ml}$ ). Bien qu'une solution plus concentrée soit disponible pour les perfusions prolongées, le vial de $100 \mathrm{mg}$ constitue un format approprié pour l'injection en bolus ou en perfusion de courte durée. Une fois un niveau désirable d'inhibition$\beta$ établi avec l'esmolol $(0,5-2,0 \mathrm{~h})$, il serait aussi efficace et moins cher de substituer une drogue à action plus prolongée comme le métoprolol $(4,64 \$$ pour l'ampoule de $5 \mathrm{ml}$ ). Pour fin de comparaison, le propanolol coûte 6,00 S l'ampoule d'un $\mathrm{ml}$.

\section{Les contreindications aux $\beta$-bloquants}

Comme tous les $\beta$-bloquants, l'esmolol est contreindiqué dans le dysfonctionnement ventriculaire droit ou gauche, l'insuffisance cardiaque ou les tachycardies non compensées de toutes étiologies. De plus, l'esmolol ne devrait jamais être administré aux patients qui présentent une bradycardie sinusale $\left(\mathrm{Fc}<60 \mathrm{~b} \cdot \mathrm{min}^{-1}\right.$ ) ou un bloc a.v. du deuxième ou du troisième degré, ou une sténose mitrale ou aortique. La cardiosélectivité de l'esmolol rend ce $\beta$-bloquant utile chez le porteur de MPOC avec réactivité bronchique, mais il est prudent de l'éviter chez l'asthmatique. Finalement, comme tous les $\beta$-bloquants, l'esmolol ne devrait jamais être administré aux porteurs de phéochromocytome à moins qu'ils ne reçoivent déjà un inhibiteur $\alpha$-adrénergique.

\section{Les inhibiteurs calciques: nouveaux produits et nouveaux rôles}

Les canaux calciquess sont des pores fonctionnelles à travers lesquelles le calcium passe en suivant un gradient électrochimique quand ils sont ouverts. Ces canaux sont présents aussi bien dans le muscle cardiaque que dans le muscle lisse, en plus d'autres membranes cellulaires; ils font aussi partie des composantes du sarcoplasme réticulaire et des mitochondries. Le calcium fonctionne comme générateur principal de potentiel du muscle cardiaque et agit aussi comme second messager intracellulaire. Les inhibiteurs calciques interagissent avec les canaux calciques de type $L$ et comprennent des médicaments de différentes classes (Tableau III).

On sait que les inhibiteurs calciques agissent en sy-
TABLEAU I $\beta$-bloquants types

\begin{tabular}{lllllll}
\hline $\begin{array}{l}\text { Classe } \\
\text { (Durée) }\end{array}$ & Elimination & $t_{t / 2} \beta(h)$ & Sélectivité $\beta_{l}$ & $A S I$ & $A S M$ \\
\hline $\begin{array}{c}\text { Ultra-courte } \\
\text { esmolol }\end{array}$ & $\begin{array}{l}\text { Estérase } \\
\text { érythrocytaire }\end{array}$ & $9 \mathrm{~min}$ & oui & \pm & \pm \\
$\begin{array}{c}\text { Intermédiaire } \\
\text { métoprolol }\end{array}$ & Hépatique & $3-4$ & oui & 0 & 0 \\
$\begin{array}{c}\text { Longue } \\
\text { propanolol }\end{array}$ & Hépatique & $4-6$ & non & 0 & ++ \\
$\begin{array}{c}\text { Ultra-longue } \\
\text { nadolol }\end{array}$ & Rénale & $14-24$ & non & 0 & 0 \\
\hline
\end{tabular}

Pharmacocinétiques des $\beta$-bloquants. $t_{1 / 2} \beta=$ demi-vie d'élimination; ASI $=$ activité sympathicomimétique intrinsèque; $A S M=$ activité stabilisante sur la membrane. $++=$ puissante; $\pm=$ marginale; $0=$ absente.

TABLEAU II Effets de la stimulation $\beta$-adrénergique

\begin{tabular}{|c|c|}
\hline Site & Réponse sympathique \\
\hline $\begin{array}{l}\beta_{1} \\
\text { Coeur }\end{array}$ & $\begin{array}{l}\text { FC † } \\
\text { Inotropie } \uparrow \\
\text { Vélocité de conduction } \uparrow \\
\text { Excitabilité } \mid\end{array}$ \\
\hline Rein & Libération de rénine \\
\hline Tissu graisseux & Libération d'acides gras libres \\
\hline $\begin{array}{l}\beta_{2} \\
\text { Vaisseaux périphériques } \\
\text { Muscle bronchique } \\
\text { Pancréas }\end{array}$ & $\begin{array}{l}\text { Vasodilatation artériolaire } \\
\text { Bronchodilatation } \\
\text { Libération d'insuline }\end{array}$ \\
\hline
\end{tabular}

TABLEAU III Inhibiteurs des canaux calciques

- Benzothiapines: diltiazem

- Phénylalkylamines; vérapamil

- Dérivés de la 1,4-dihydropyridine: nifédipine, nicardipine, nitrendipine

nergie avec les anesthésiques volatils pour déprimer la cinétique des canaux calciques lents. " De plus, il est prouvé que les inhibiteurs calciques interagissent avec les myorelaxants non dépolarisants d'une façon indentique à celles des antibiotiques du type " mycine ". 12 Bien qu'on connaisse mal cette interaction, la marge de sécurité semble diminuée lorsqu'on associe ces drogues. Malgré ces considérations, l'expérience clinique a démontré, que comme les $\beta$-bloquants, les inhibiteurs calciques devraient être administrés jusqu'au moment de la chirurgie pour contrôler l'angine, l'hypertension ou les dysrhythmies cardiaques. ${ }^{12}$ Il est possible que l'arrêt subit de ces drogues puisse causer un rebond des symptômes, ce qui n'a pas encore été rapporté. 


\section{La nifédipine}

La nifédipine, comme tous les dérivés de la dihydropyridine, est un vasodilatateur artériolaire puissant sans effets vénodilatateurs. L'activation réflexe du système nerveux sympathique peut provoquer des augmentations de la fréquence cardiaque et de la contractilité. Les effets inotropes négatifs de la nifédipine sont en général contrebalancés par une augmentation de la résistance vasculaire systémique, avec un augmentation simultanée du débit cardiaque. Grâce à leurs effets vasodilatateurs, tous les dérivés de la dihydropyridine sont des excellents antihypertenseurs.

La biodisponibilité de la nifédipine orale est d'environ $70 \%$, avec une concentration plasmatique maximale après 30-45 min de son administration. La drogue est liée à 95\% au protéines et possède une demi-vie d'élimination de cinq heures. Comme ce médicament se dégrade rapidement en présence de lumière et d'humidité, la présentation parentérale de la nifédipine n'est malheureusement pas encore approuvée et par conséquent, non commercialisée. Cependant, par ponction de la capsule et administration nasale ou sublinguale, la nifédipine agit en deux ou trois minutes. ${ }^{13}$

\section{La nifédipine pour traiter l'hypertension postopératoire}

De trente à soixante pour cent des patients souffrent d'hypertension après une chirurgie de dérivation myocardique ou un remplacement valvulaire aortique. Il en résulte un stress hémodynamique important qui prédispose au saignement, à l'ischémie myocardique et à l'infarctus du myocarde. ${ }^{14}$ Aussi, l'extraction myocardique du lactate diminue pendant l'hypertension postopératoire, comme le prouve l'apparition du métabolisme anaérobique lactique hétérogène. ${ }^{15}$ Au cours des 15 dernières années, le nitroprussiate de soude a joué un rôle de première classe dans le traitement de lhypertension postopératoire. Bien que l'administration de nitroprussiate soit très efficace pour contrôler cette condition, elle se complique quelquefois d'une intoxication au cyanure et au thiocyanate, et à une baisse de la tension de l'oxygène artériel, conséquence de l'inhibition de la vasoconstriction pulmonaire hypoxique. Il a aussi été démontré que le traitement par le nitroprussiate de l'hypertension postopératoire était associé à une inversion de la production de lactate, sans diminution du débit sanguin du sinus coronarien, ce qui suggère un vol intra-coronarien. ${ }^{15}$

Il faut donc considérer d'autres options thérapeutiques pour traiter l'hypertension périopératoire chez le patient sujet à l'ischémie myocardique. Récemment Mullen $e t$ al. ont comparé l'efficacité et les effets cardiaques et métaboliques de la nifédipine avec ceux du diltiazem et du nitroprussiate pour le traitement de l'hypertension postCEC. ${ }^{16}$ Ils ont trouvé que lorsqu'une des trois drogues était administrée pour maintenir la tension artérielle près de $90 \mathrm{mmHg}$, la performance myocardique (la relation entre lindex systolique du travail du ventricule gauche et le volume télédiastolique) était réduite à un plus grand degré par le diltiazem, à un degré moindre par la nifédipine, mais aucunement par le nitroprussiate. A l'inverse, en réponse au stress de l'entrânement électrique auriculaire, le flux de lactate myocardique diminuait avec le nitroprussiate, mais non avec le diltiazem et la nifédipine.

A l'heure actuelle, le nitroprussiate demeure une drogue très efficace pour le contrôle de l'hypertension postopératoire, mais possiblement nuisible dans l'ischémie myocardique de la période postopératoire. La nifédipine peut donc représenter un médicament d'appoint quand l'hypertension postopératoire s'accompagne d'une augmentation de la contractilité, ce qui permet de diminuer le métabolisme myocardique. Cependant, il faut utiliser les inhibiteurs calciques avec prudence lorsque la réserve ventriculaire est limitée. Les préparation parentérales de nifédipine et de diltiazem ne sont pas encore approuvées pour usage in Canada.

Pour le traitement de l'hypertension postopératoire, la nifédipine peut être administrée par la voie sublinguale ou intranasale. La dose initiale est de $10-20 \mathrm{mg}$, à répéter après 15 ou $20 \mathrm{~min}$ si nécessaire. Ses principaux avantages résident dans son efficacité, ses effets cardiovasculaires favorables et son coût $(0,12 \$$ par capsule de $10 \mathrm{mg})$.

\section{La nicardipine}

Les effets de la nicardipine ressemblent à ceux de la nifédipine mais avec une sélectivité plus grande pour les lits coronaires et vasculaires et une action encore plus prolongée. Les concentrations plasmatiques maximales sont atteintes une heure après l'administration orale avec une biodisponibilité de 35\%. La drogue subit une biotransformation hépatique considérable avec une demi-vie d'élimination de 8 à $9 \mathrm{~h}$. Bien qu'un pour cent de la drogue seulement ne soit excrétée par le rein, les concentrations plasmatiques sélèvent chez les insuffisants rénaux. Il faut pratiquer des ajustements posologiques chez ces patients.

Bien que la nicardipine ne soit pas encore approuvée au Canada, on peut l'utiliser à la période périopératoire par voie parentérale. Cette drogue peut être utile pour traiter l'hypertension postopératoire, particulièrement chez le coronarien. En effet, la nicardipine améliore considérablement le débit coronarien, ce qui serait le résultat d'une vasodilatation coronarienne directe. De plus, la nicardipine a des effets inotropes positifs soit par son action sur les phosphodiestérases soit par son activité agoniste sur les canaux calciques; il en résulte une augmentation du débit sanguin coronaire par autorégulation. 


\section{La nitrendipine}

La nitrendipine est un dérivé de la dihydropyridine qui diffère de la nifédipine par son activité vasculaire dilatatrice plus sélective et un effet dépresseur moindre sur le myocarde. La nitrendipine a aussi des effets natriuriques et diurétiques importants, bien que le taux de filtration glomérulaire et le débit rénal ne soient pas modifiés. L'avantage clinique principal de la nitrendipine est constitué par sa demi-vie d'élimination prolongée (8-10 h), ce qui permet de traiter les hypertendus et les insuffisants cardiaques avec une seule prise quotidienne du médicament.

\section{Autres nouveaux antihypertenseurs}

Le système rénine-angiotensine-aldostérone joue un rôle important dans la pathogénèse de l'hypertension. L'introduction récente d'une préparation parentérale de l'inhibiteur de l'enzyme de conversion de l'angiotensine (ECA), l'énaliprilat nous permet de réexaminer les avantages thérapeutiques de cette classe de médicaments pour le traitement en urgence des épisodes hypertensifs de la période périopératoire. La facilité d'administration représente un avantage pour un inhibiteur de l'ECA (un bolus iv q6H); ce qui est plus important encore, cette classe de drogues permet une diminution sous contrôle de la pression artérielle avec préservation du débit sanguin aux organes vitaux.

La rénine est libérée à l'appareil juxtaglomérulaire en réponse aux changements de pression artérielle. Elle segmente la glycoprotéine angiotensine du plasma pour former le décapeptide angiotensine I. L'ECA agit sur l'angiotensine I pour former l'octapeptide angiotensine II. L'angiotensine II qui est le plus puissant vasopresseur connu élève la pression artérielle directement par vasoconstriction du lit artériolaire, et indirectement par stimulation de la sécrétion d'aldostérone par les glandes surrénales, favorisant ainsi la rétention d'eau et de sodium. Dans des conditions normales, une boucle rétrocontrôle la libération de rénine, mais dans plusieurs types d'hypertension, un niveau élevé d'activité du système RAA conduit à des concentrations élevée d'angiotensine II, ce qui aggrave l'hypertension. Ces mécanismes pourraient jouer un rôle important dans le physiopathologie de l'hypertension périopératoire.

\section{L'énaliprilat}

Présentement, l'énaliprilat est le seul inhibiteur de l'ECA approuvé pour administration parentérale. On a montré que cette drogue était efficace pour abaisser la pression systolique et diastolique des d'hypertendus graves. ${ }^{18} \mathrm{La}$ principale action de l'enaliprilat consiste à diminuer la concentration de l'ECA et de provoquer une baisse subséquente de l'angiotensine II. On a suggéré que les in- hibiteurs de l'ECA pourraient être inutiles chez le patient dont l'activité de la rénine plasmatique est normale, mais des études ont montré que la réponse hypotensive à ce groupe de drogues n'était pas plus reliée au niveau basal de la rénine plasmatique qu'à la baisse du niveau de l'angiotensine II; ${ }^{19} \mathrm{ceci}$ attribue un rôle à l'augmentation de la production des prostaglandines vasodilatatrices ou à d'autres mécanismes pour expliquer les effets antihypertenseurs de la drogue.

En plus d'être efficace pour le contrôle des crises hypertensives, l'énaliprilat $\dot{i}$ atténue la réponse hémodynamique à l'intubation. ${ }^{20,21}$ Cependant, son début d'action est relativement long ( $15 \mathrm{~min}$ ) et le stimulus de l'intubation transitoire; son utilisation paraît mieux adaptée à des situations où l'augmentation de la pression artérielle est progressive et maintenue, ${ }^{23,24}$ comme il s'en présente à la période postopératoire. Cette drogue offrirait donc des avantages pour le contrôle de l'hypertension post-CEC ou après une chirurgie vasculaire majeure. La dose initiale recommandée est de $1,2 \mathrm{mg}$ iv administrée en cinq minutes répétable aux $6 \mathrm{~h}$ au besoin. Si la réponse est inadéquate, la dose initiale peut être répétée après une heure. Le coût de ce traitement est de $42 \$$ par jour (l'enaliprilat coûte $20,79 \$$ par ampoule de $2,5 \mathrm{mg}$ ). Il faut diminuer la dose de moitié chez l'insuffisant rénal, ou lorsque qu'li'y a danger d'hypotension. L'action débute en 15 min mais l'effet antihypotenseur maximal survient entre une et quatre heure. Bien que la principale indication de l'énaliprilat soit le traitement de l'hypertension, on a montré qu'il augmentait modérément la pression télédiastolique ventriculaire gauche et artérielle pulmonaire, avec une augmentation consécutive du débit cardiaque et du volume systolique.

En général, la fiabilité et la tolérance à l'énaliprilat intraveineux sont identiques à celles de la préparation orale. L'hypotension constitue son effet secondaire le plus fréquent et survient chez environ $4 \%$ des patients dont les plus susceptibles sont les insuffisants cardiaques, les hyponatrémiques et ceux qui viennent de subir une diurèse intense. On peut diminuer l'hypotension en réduisant la dose initiale de moitié ou en réalisant un remplissage vasculaire préventif. De plus, les effets antihypertenseurs de l'énaliprilat peuvent être exagérés par les antihypertenseurs qui libérent de la rénine (ex. les diurétiques). Comme l'énaliprilat atténue la perte de potassium provoquée par les diurétiques, l'association à l'énaliprilat de diurétiques qui ont un effet d'épargne sur le potassium nécessite le monitorage de la kaliémie.

\section{Les antiarythmiques: nouveaux médicaments ou nouvelles indications}

La fréquence des arythmies pendant l'anesthésie et la chirurgie dépend de la définition de l'arythmie et de la sen- 
sibilité de la méthode de détection. Lincidence varie considérablement selon les études, mais pourrait approcher $100 \%{ }^{24}$ Heureusement, malgré cette incidence, les troubles du rythmes graves nécessitant traitement par cardioversion pharmacologique ou électrique sont rares. Si une arythmie supraventriculaire doit être traitée, l'adénosine est une nouveau médicament qui offre des avantages uniques. Pour la fibrillation ventriculaire rebelle ou pour le traitement de la torsade de pointes, un vieux médicament trouve sa place, le sulfate de magnésium.

\section{L'adénosine}

L'adénosine est une ribonucléoside naturelle décrite en 1929 mais acceptée tout récemment pour usage clinique au Canada. Elle est maintenant considérée comme le médicament de choix pour le traitement de la tachycardie supraventriculaire, ${ }^{25,26}$ en ralentissant la vitesse de conduction du noeud $\mathrm{AV}$, et en terminant le réentrée nodale. A plus fortes doses, l'adénosine peut déprimer le noeud sino-auriculaire et l'automacité ventriculaire.

La plus remarquables des caractéristiques de l'adénosine est son début rapide et sa courte durée d'action (demi-vie d'élimination $=1,5 \mathrm{sec}$ ). Bien que l'efficacité de l'adénosine pour le traitement de la tachycardie supraventriculaire soit identique à celle du vérapamil, l'adénosine n'a pas les effets vasodilatateurs et inotropes négatifs de celle-ci. D'une autre côté, l'adénosine est associée fréquemment aux effets secondaires transitoires et désagréables dont la gêne thoracique, la dyspnée et l'érythème facial qui ne durent qu'une ou deux minutes. Exceptionnellement, on rencontre une bronchoconstriction qui peut durer une heure. L'action de l'adénosine est antagonisée par les dérivés de la théophylline, mais peut être potentialisée par le dipyridamole.

La dose initiale d'adénosine recommandée est de $6 \mathrm{mg}$ iv pour les adultes, administrée en deux ou trois secondes. Si on n'obtient pas de réponse après une ou deux minutes, une dose de $12 \mathrm{mg}$ est administrée de la même façon. Il est important que l'adénosine soit administrée par une ligne veineuse qui coule rapidement parce que la drogue est complètement métabolisée en moins d'une minute. A cause de ses effets cliniques de courte durée, les tachyarythmies peuvent se répéter, ce qui nécessite une dose additionnelle d'adénosine ou un inhibiteur calcique. L'adénosine coûte $29,50 \$$ pour une ampoule de $6 \mathrm{mg}$.

L'adénosine provoque aussi de nombreuses interactions. Comme les méthylxanthines bloquent les récepteurs responsables de l'activité électrophysiolgique et hémodynamique de l'adénosine, les patients sous l'aminophylline et ses dérivés peuvent avoir besoin de doses plus fortes d'adénosine. De plus, le dipyridamole inhibe la capture de l'adénosine et potentialise ses effets; la carbamazépine prolonge aussi l'action de l'adénosine.

\section{Le sulfate de magnésium}

Le magnésium est un cation intracellulaire bivalent ordinairement abondant dans l'organisme mais dont la concentration peut être insuffisante chez le malade chronique. Fonctionnellement, le magnésium est un régulateur primaire ou un co-facteur de plusieurs systèmes enzymatiques requis pour le maintien de l'ATPase $\mathrm{Na}^{+} /$ $\mathrm{K}^{+}$, le principal enzyme responsable du maintien de la kaliémie intracellulaire. L'hypomagnésémie $(\mathrm{Mg}<1,7$ $\mathrm{mg} \cdot \mathrm{dl}^{-1}$ ) survient souvent pendant la chirurgie cardiaque ${ }^{27}$ et est associée à de nombreux désordres cardiaques dont les arythmies, la défaillance, le spasme coronarien et la mort subite..$^{28}$ De plus à l'instar de l'hypokaliémie, l'hypomagnésémie prédipose aux arythmies provoquée par les glycosides digitaliques. ${ }^{19}$ Les caractéristiques électrocardiographiques de l'hypomagnésémie sont identiques à celles de l'hypokaliémie, dont le prolongement des intervalles $\mathbf{P}-\mathbf{R}$ et $\mathrm{Q}-\mathrm{T}$, le prolongement de la durée du QRS et les anomalies du segment ST. Les manifestations non vasculaires de l'hypomagnésémie sont la tétanie. latente ou déclarée, la faiblesse, la baisse de la conscience et les convulsions; on rencontre aussi de la dysphagie, de l'anorexie et de la nausée.

On sait que les arythmies causées par une déficience en magnésium peuvent être réfractaires au traitement par les antiarythmiques, aussi ,bien qu'à la cardioversion et à la défibrillation. Pour cette raison, le traitement des arythmies réfractaires par le magnésium a été proposé même en absence d'une hypomagnésémie prouvée. Le magnésium est aussi présenté comme le médicament de choix pour le traitement de la torsade de pointes, une tachycardie ventriculaire de type polymorphe.

Le rôle du magnésium dans la mort cardiaque subite fait présentement l'objet d'une réévaluation. ${ }^{30}$ Dans l'infarctus aigu du myocarde associé à une hypomagnésémie, le risque d'insuffisance cardiaque avec mort subite est augmenté; des études récentes suggèrent que l'administration de magnésium même en absence d'une hypomagnésémie pourrait diminuer ce risque. Cet effet du $\mathrm{Mg}^{++}$résulterait de sa capacité d'inhiber la libération de catécholamines, de dilater les coronaires et d'augmenter la libération de prostacycline, ce qui diminue l'adhésion et l'aggrégation plaquettaires. Le rôle que pourrait jouer l'administration systématique de $\mathrm{Mg}$ lors de l'infarctus du myocarde est présentement à l'étude. A l'heure actuelle, il semble quil soit prudent de corriger l'hypomagnésémie dans un contexte dischémie myocardique, d'arythmies ventriculaires et d'insuffisance cardiaque. Pour l'hypomagnésémie symptomatique ou grave $\left(\mathrm{Mg}^{++}\right.$ $<1 \mathrm{mg} \cdot \mathrm{dl}^{-1}$ ), le traitement consiste à administrer $\mathrm{du}$ magnésium parentéral 1-2 $\mathrm{g}(8-16 \mathrm{mEq})$ en bolus pour la première heure, suivi d'une perfusion à la vitesse de 2-4 $\mathrm{mEq} \cdot \mathrm{h}^{-1}$. Le traitement doit être guidé par la 
TABLEAU IV Caractéristiques désirables de linotrope idéal

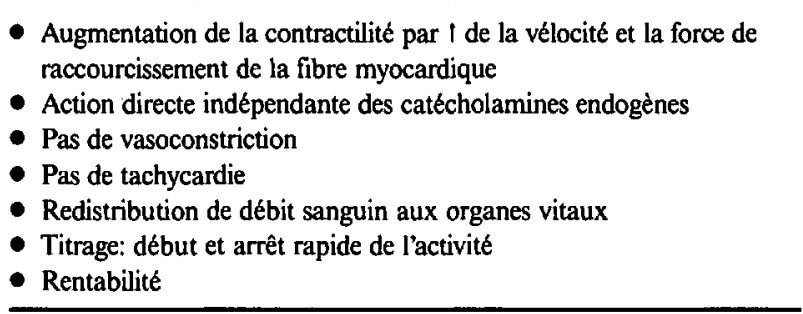

magnésémie et ne devrait jamais dépasser $1 \mathrm{mEq} \cdot \mathrm{min}^{-1}$, même en urgence. L'ECG et la pression artérielle doivent être monitorés pendant le traitement, alors que lors de déficits légers, le traitement est constitué d'un régime alimentaire seul ou avec des suppléments de $\mathrm{Mg}^{++} p o$.

\section{Acquisitions récentes de la thérapeutique inotrope}

Un nouveau groupe de drogue dont les propriétés s'approchent de celles de l'inotrope idéal (Tableau IV) a fait son apparition. Ces nouveaux inhibiteurs des phosphodiestérases n'agissent pas par stimulation des récepteurs $\beta$-adrénergiques ou $\alpha$-adrénergiques mais plutôt par inhibition sélective de la PDE III. Ainsi, cette classe de drogues améliore la fonction cardiaque sans augmenter la consommation d'oxygène. La PDE I, comme la PDE II hydrolyse toutes les nucléotides cycliques, alors que la PDE III agit spécifiquement sur la cAMP pour empêcher sa dégradation au niveau de la membrane cellulaire. Dans le muscle cardiaque, l'élévation de la cAMP contribue à la phosphorylation, qui elle-même augmente le mouvement lent du courant calcique vers l'intérieur, favorisant ainsi le stockage du calcium intracellulaire et l'inotropisme.

\section{L'amrinone}

L'amrinone est un dérivé de la bipryridine avec un inotropisme faible et une puissante activité vasodilatatrice. ${ }^{31,32}$ Bien que couramment prescrite sous sa forme parentérale, l'amrinone est le premier inotrope oral apparu depuis l'introduction de la digitale. L'amrinone a une index thérapeutique élevé $\left(\mathrm{LD}_{50} / \mathrm{ED}_{50}\right)$ d'environ 100:1 comparativement à 1,2:1 pour les glycosides digitaliques. Ce haut niveau de sécurité peut être mis à profit pour la thérapie à long terme.

L'amrinone provoque une augmentation proportionnelle à la dose de l'index cardiaque et de l'index du travail du ventricule gauche (40-80\%) associée à une baisse de la pression ventriculaire télédiastolique et de la résistance vasculaire systémique. Il est important de noter que la fréquence cardiaque et la pression artérielle sont peu affectées. La réponse maximale à une dose $i v$ survient en moins de cinq minutes, et on n'a pas démontré de tolérance à court terme $(24 \mathrm{~h})$. La drogue est compatible
TABLEAU V Prise en charge du syndrome de bas débit

- Confirmer l'efficacité de l'oxygénation et de la ventilation

- Procurer l'analgésie et la sédation nécessaires

- Initier un monitorage effractif

- Optimiser la précharge ventriculaire

- Corriger les anomalies métaboliques

- Traiter les arythmies

- Apport pharmacologique

1 Vasodilatateurs

2 Inotropes

3 Diurétiques

- Support mécanique de la circulation et traitement chirurgical si indiqué

avec d'autres agonistes adrénergiques et peut être utilisée efficacement avec d'autres vasodilatateurs comme l'hydralazine.

La dose initiale est de $0,75 \mu \mathrm{g} \cdot \mathrm{kg}^{-1}$ en bolus administré en 2-3 min, suivi d'une perfusion de 5-10 $\mu \mathrm{g} \cdot \mathrm{kg}^{-1} \cdot \mathrm{min}^{-1}$, ajustée au profil hémodynamique. On peut donner un autre bolus de $0,75 \mu \mathrm{g} \cdot \mathrm{kg}^{-1}$ à 10 ou $20 \mathrm{~min}$ du bolus initial. In faut administrer ces bolus lentement par crainte de provoquer de l'hypotension. Deux effets secondaires de l'amrinone d'importance clinique mais rares attirent l'attention. En premier lieu, la thrombocytopénie qui survient occasionnellement pendant la médication orale à long terme de l'amrinone. Heureusement, la situation se rétablit si on diminue la dose; cette complication n'a pas été rapportée lors de l'administration parentérale à court terme. ${ }^{33}$ Un deuxième effet secondaire, une nécrose hépatique centrolobulaire a été découverte chez les chiens recevant de hautes doses du médicament pour des périodes de plus de trois mois. Bien que cette complication n'ait pas été rapportée chez l'humain, il vaut mieux ne pas administrer d'amrinone à des patients sous halothane.

Finalement, le traitement du syndrome de bas débit cardiaque doit suivre les principes généraux schématisés au Tableau V. L'amrinone coûte relativement cher $(32,40 \$$ pour $100 \mathrm{mg}$ ). En comparaison, la dopamine coûte $1,02 \$$ pour $200 \mathrm{mg}$ et la dobutamine $31,30 \$$ pour $250 \mathrm{mg}$. Lorsqu'on choisit un inotrope pour faire face à une situation spécifique, il faut tenir compte des bénéfices potentiels procuré par l'amélioration de la fonction cardiaque sans augmentation de la consommation myocardique d'oxygène (amrinone) et avec réduction des besoins simultanés en vasodilatateurs (lorqu'on utilise l'amrinone ou à un degré moindre la dobutamine).

\section{Le milrinone}

Le milrinone est un inotrope expérimental dérivé de la bipryridine qui possède vingt fois la puissance de son congénère. ${ }^{34} \mathrm{La}$ milrinone est active par les voies veineuse et orale, et est efficace à court terme pour traiter lin- 
suffisance réfractaire globale grave. Comme pour l'amrinone, l'amélioration de la dysfonction cardiaque est le résultat de l'augmentation de la contractilité et de la vasodilatation périphérique. Son efficacité reste à établir chez l'humain.

\section{Conclusion}

Plusieurs nouvelles médications cardiaques constituent le pilier du traitement de candidats à la chirurgie cardiaque ou non cardiaque qui doivent recevoir une anesthésie. En général, ces médicaments doivent être continués à leur dose usuelles jusqu'au matin de la chirurgie inclus et doivent être repris dans la période postopératoire immédiate. Il est important de reconnaïtre le potentiel dinteraction avec les anesthésiques aussi bien qu'avec les autres médications cardioactives administrées à la période périopératoire. Il faut de plus retenir que les nouveaux médicaments à courte action comme l'esmolol et l'adénosine sont faits sur mesure pour le contrôle de la tachycardie, des arythmies et des perturbations hémodynamiques. Des considérations d'efficacité, de facilité d'administration, de profil des effets secondaires et du rapport coût-bénéfice (pharmacoéconomique) détermineront le rôle ultime de ces nouvelles acquisition dans notre pratique clinique.

\section{Références}

(Voir page R112) 